\title{
Learning from The Mahabharata For an Anew Contemporary Political Understanding
}

\author{
K C Mishra \\ Principal, Sambhram Academy of Management Studies \\ M S Palya, Jalahalli East, Bangalore, India \\ E-mail: mishrakc847@gmail.com
}

Received: September 9, 2020 Accepted: October 13, 2020 Published: October 14, 2020

doi:10.5296/jpmr.v6i2.17823 URL: https://doi.org/10.5296/jpmr.v6i2.17823

The Indian Spiritual Epic, the Mahabharata, is a precise write up of Indian mythology of yesteryears and the way social life was led by the top Statesmen who were at the helm of all societal affairs. The Indian Holy Scripture, the Bhagavad Gita, the socio-philosophicalliterature of the Indian Socio-Cultural Milieu, also find special place within the Mahabharata in the format 'Special Dialogue', otherwise can be quoted as Spiritual Discourse. This literary work originally composed in Sanskrit, the Mother of all Indian Languages, sometime between $400 \mathrm{BC}$ and $400 \mathrm{AD}$ is set in a legendary era thought to relate to the period of Indian culture and history approximately during the tenth century BC.

For Indians, politics is something they are especially interested which remains untouched without knowing The Mahabharata. In the Indian politicized society, people understand their democratic rights and at the time of elections passions and emotions run very high and people talk of their elected representatives who have to represent them in the State Assembly and Indian Parliament to manage the whole gamut of societal issues and administration. They don't forget to quote anecdotes from The Mahabharata which is the inevitability; the uniqueness is how the Indian psyche relates to it. They make no distinction between caste and creed; it breathes in the masses of India with a combination of philosophy of life, tradition and heritage; even the uneducated and illiterate ones shared these realizations in the rudimentary form as it appears.

The Mahabharata is about retaining the political rein, enjoying the social strata, preservation and patronage of local cultures and transforming humanity through experience; such themes never get outdated. Having unique strategies, it focuses on political and military supremacy and the Master Strategist and the Torch Bearer of Righteousness Lord Krishna justifies use of strategies in National Interest and war inevitability at times of decaying State of Truth or when people forget to cling to truth. Some of the strategic features about Mahabharata which even today can teach the World Leaders are: 
Karna was kind, humble and generous which is not enough for the State Administration today

* An evil companion (Shakuni) can mar anything and everything beyond reparability

* Unstinted support of Friends like Lord Krishna can work wonders

* If one does not get his due genuinely; one has to fight to acquire

* The over-emotional State is the appropriate idea

* Those who resort to learning all their lives like Arjun; do attain the point of zenith

* Half knowledge of anything can prove fatal than no knowledge (Abhimanyu)

\& No one can deter anyone's aspirations (Eklavya)

* The noteworthy worldly lesson from The Mahabharata is Worth of Strategy, Right and Just In Time and the Approach to Life

* Lord Krishna is remembered both for righteousness and deviating from righteousness

Unity of Command among Five Pandavs ensures victory at last

The Mahabharata reminds that today's politicians forget their moral duty and how they dissociate themselves from the social reality and the common mass; it is the experience of those times when people really awaited for a true savior; it is also the pitiable saga of a blind King's savage-impure faith in his power-lust, incompetent, immoral, unfaithful, uncivilized and incorrigible son Duryodhana. With changing scenario, different political groups and personalities start resembling different situations, camps and characters of The Mahabharata. Anytime there are unholy congresses of courtiers, Kauravas are remembered and incase there seems to be a right person in the wrong camp, Bheeshma, Drona, Kripacharya or Karna comes to the centre-stage.

The Mahabharata shows great focus on imagination beyond the possibility and opens up new vistas of thought and attracts electro-magnetic moments of truth for which it even remains supreme than all other contemporaries today. We have to accept with humility the astounding wisdom of Maharshi Vyas and it's not true to forget high moral of the ancient and acclaim in the power of his imagination which could grasp the innermost aspirations of humankind. Today's politicians and the common alike assimilate with this because it portrays their own thought processes, actions and the realities. Aspirations of the human being, the insatiate intensity for mundane desires, and also the desire to dominate others, all the good and the bad of human nature: this marvel of literature tells it all and presents in a classic way; the Eternity Moves and The Mahabharata never stops enlightening all of us about our Inner Self.

\section{Lessons from the Pandavas}

When the enemy is in-genuine and resorts to all kinds of wrongs, we have to change tactics to win; when it was crystal clear that the Kauravas and Pandavas were to have the decisive war, both Arjun and Duryodhana met Lord Krishna seeking his all powerful support. Krishna was in the state of sleep when the duo arrived; they then decided to wait till he awakened. The proud Duryodhana sat near Krishna's head; with love and in adoration Arjun sat at the feet of Krishna. When Krishna saw Arjun after awakening and then Duryodhana, he declared that he will not lift any weapon, nor even participate in the war and gave options to his both cousins 
to choose either he or his ever powerful the Narayani Sena. Arjun was clever to choose Krishna knowing very well that the latter was not going to fight in person. Next, Duryodhan was very happy to have the mighty force which proved to be unbecoming because he afterwards learnt; a battle is not only clash of weapons or fight among the warriors but a clash between strategists of wits and wisdom, of time and choices.

Born of two mothers (Yudhishthir, Bheem and Arjun to Kunti and Nakul and Sahadeva to Madri); Pandu's five heirs, the Pandavas have different skills, viewpoints, and their own strengths and weaknesses; yet they all reposed their faith to accept the final decision of the eldest Pandava Yudhishthira. Their unity was their main power; whatever may be the dispute they stayed in unison even long after winning the war and right till their deaths; this proved that collective strength is better than acting independently. This applies to re the real-life situations and challenges even today for the World Statesmen; a good and functional team of a Nation focuses on the objectives of the Government, resolves conflicts, respects each member's views and does the best in the direction of Right Governance. Even World Peace can be ensured if Statesmen of Countries develop holy relationship among themselves. Pandavas showed expertise in team-building thus achieve their mission.

Sometimes, one has to taste defeat to some extent to win the bigger war: Abhimanyu was a great warrior ever the human race had had but he misread Kauravas' master-strategy-plan and got himself enveloped into the Chakravyuha which was a very delicate setting which at first disallows the warrior to get into the inner circles but once he does breach it, he must have the exact knowledge to find his way out of the trap. He did the impossible to breach it to enter but the history is that his mother Subhadra was asleep when she was pregnant having Abhimanyu in her womb and husband Arjun was narrating the Chakravyuha breaching coupled with escape science. She was conscious till the entry part was narrated but fell asleep when the escape part was being told; therefore, Abhimanyu never knew how to escape from the Chakravyuha. Even a warrior of the stature of Abhimanyu had to fall prey to the enemy because he had only half plan and lacked the knowledge in entirety about what the enemy could do.

Life poses tough challenges and many a times bleeds us emotionally; Arjun had to accept killing family patriarch Bhishma Pitamaha and Guru Dronacharya who had sided with the wrong force. They both loved the Pandavas but because Dhritarashtra was still the King of Hastinapur, their loyalty first remained with the Kauravas - the 100 sons of Dhritrashtra and Gandhari.

Bhishma was from the enemy force, Arjun had to weed him out to advance in the war. And so must the Pandavas kill Guru Dronacharya, Arjun was in total emotion completely shocked and defeated in the mind for he did not want to kill these near and dear.

Lord Krishna, his charioteer, taught him lessons about the realities of life; that we have to do our duty or karma assigned to us; the fruit, the outcome is not our choice, duty or responsibility. Then Arjun had to emotionally get away himself from his kith and kin that awaited him at war.

\section{No Point in Occupying the High Moral Ground if One Lose in the Process}


Contemporary politics is often halfway through without the high moral ground, no matter the cost and this mode of thinking led to a disastrous war to India against China in 1962. Even today China considers India is in 1960s but not in 2020s. In the Mahabharata, Krishna recommends use of different strategies in the service of moral causes and also in the interests of the State; the ends justify the means when major issues are at stake.

\section{War Is Justified at Times}

The Indian legacy has been exclusively non-violent because of the advent of the apostle of the Peace Mahatma Gandhi; he viewed it would be better to uphold and cherish the principle of non-violence than resorting to violence for anything, even for self-defense. On the other hand, the Mahabharata accepts the idea of a just war as a matter of basic premise to restore righteousness in the administration. Shakuni accepted that the war is the option which should only be resorted to only when all kinds of political solutions fail; but once the war is in place, it ought to be fought till the end in true spirit of the war. Krishna discoursed Arjun once a war breaks out it is not only the just but mandatory to fight as it ensures peace and alone peace as the end result. It is also right to resort to war to bring the genuine conclusion rather than to walk away from violence following the principle of non-violence.

\section{Rules and Customs Ought to Be Interpreted Flexibly}

During the Mahabharata, both Krishna and Shakuni favored rules and customs should serve certain social limits of social functions and the moment they cease to do so, they should be discarded; duty can thus be appropriately amended when it undertakes certain course of action that is inflexible. The Panadavas felt it to be their dignity to play a game of dice till the end despite the fact that it resulted in the gambling away of their kingdom and their own queen. Today it's seen somewhere in India that following a narrow rule-based social principle leads to caste/community-based discrimination or violence against women; such a strict sense of pseudo-morality leads to actions that are also immoral, then it is better to assess one's notion of duty and honor.

\section{Whither Mahabharata}

Socio-polity-philosophical works are thrown open throughout the Mahabharata as dialogues between characters involved in political and military situations. The Mahabharata is a concrete example of ancient Indian Game of Thrones with various factions competing for political power and authority in a variety of states; it is a dynastic struggle for the throne of Hastinapura (located between modern Delhi and western Uttar Pradesh), the kingdom ruled by the Kuru clan.

Two branches of cousins of the Kuru family are fighting for the throne: the Kauravas and the Pandavas. Although the father of the Kauravas is the elder brother of the Father of the Pandavas, he is initially disqualified from ruling in favor of his younger brother as he was blind. His eldest son, Duryodhana, claims to be the rightful heir-apparent to lead the Kuru dynasty on the basis of being the eldest son of the eldest son even though the eldest Pandava, Yudhisthira, is older than him and is considered the legitimate heir apparent. Eventually, the struggle between the Kauravas and Pandavas ends in the great battle of Kurukshetra in which 
the Pandavas ultimately came out victorious. Throughout the wonderful scenario, it is implied that the Pandavas are on the right path because they followed dharma (righteousness).

The Mahabharata is well received across the human race because it reflects that the Indian tradition contains more than the idealism and non-violence exemplified by personas such as Mahatma Gandhi, Acharya Vinoba Bhave, Lal Bahadur Sastri, Jayaprakash Narayan and Morarji Desai which contains advice that is similar to the wisdom and real politics of Sun $\mathrm{Tzu}$ and Machiavelli - the practical strategies serving the ultimate agenda of political and military victory. The two main key figures in the Mahabharata who espouse on these strategies are Shakuni, the maternal uncle of the Kauravas, and Krishna, the maternal cousin of the Pandavas; Krishna is the Avatar-God-Incarnate. Together these two personalities espouse on a variety of political strategies that could be of practical political relevance today to restore world peace. Even any Pandemic can be fought with such righteousness as from the beginning people lead a principled way of life espousing the dictum 'Cleanliness in next to Godliness'. This is extremely important as it gives Indians a practical-socio-philosophical way of looking at the world rooted in the ancient Indian civilization.

The most pragmatic useful commandments the politicians of today to receive, particularly those, who using any and every means try to cling to power radiates, from one of the last in this series of conversation: 'What is the most surprising phenomenon in this world'; answers Yudhisthira to Yaksha, every moment we see people around us departing to the abode of the God of Death, yet those alive wish never to die.' What, indeed, could be more surprising than this dictum?

\section{Dialogue Between Krishna and Karna}

Karna to Lord Krishna: my mother left me soon I was born; was it my mistake that I was born an illegitimate child? No scope to study under the tutelage of Guru Dhronacharya because I was considered as a non-Kshatriya; Parsuram taught me but ultimately cursed me to forget everything when he came to know that I was the son of Kunti and belong to Kshatriya clan. I was insulted in Draupadi's Swayamvar. My birth-mother Kunti finally told me the truth only to save her other sons from defeat. Finally whatever I have received was through Duryodhana's charity so how can I be wrong in taking his side?

Lord Krishna to Karna: my birth place is jail and death awaited for me well before my coming from the mother's womb; that horror night after I was born soon got separated from the birth parents. As a child you grew up seeing the swords, chariots, horses, bows and arrows but me only could see cow herd's shed and dung. I had to face multiple death-attempts on my life as a toddler. People said I am the reason for all their problems but you received all sorts of appreciation for valor by your teachers; I didn't even receive any education. I had the scope to join Gurukul of Rishi Sandipani when I was sixteen. Your spouse was of your choice, I ended up marrying those who wanted me or the ones I rescued them from demons.

To save my community people from Jarasandha, I moved them too far off the sea from the banks of Yamuna; I was treated as a coward for running away. You will enjoy if Duryodhana wins the battle but what would be my credit if Dharmaraja wins the war; only the blame for the war and all related problems. Karna remember, everybody has challenges in life to face 
but what is Right (Dharma) is known to your conscience, do you follow?

How much unfairness we have to face, how many times we face disgraced, how many times we fall, the most important law of life is how we react at that point of time. Unfairness in the way of life does not give us license to walk the wrong path; so always remember, life may be tough at few instances but destiny is not something can be created by us rather everything depends on the steps we take.

\section{The Last But Not the Least Say}

The message of The Mahabharata is perennial for the whole human race because of its signal 'Pure Truth Unspoken' what can be called as 'Universal Truth'. The nature of truth is always old and new; one may look at truth a thousand times but its beauty never die, every moment the truth reinvents itself and presents itself before the human race in the newness of it. The more we consume truth, the more nectar we get out of it. In essence, the epic narratives represent an extended exploration of the responsibilities set forth by the dictum of the code of dharma what is called as Righteousness. Establishing this epic as the Rightful Legend, the Mahabharata contains texts on a broad horizon of human learning which include: history, socio-ethics, law, philosophy, morality and religious sentiments; with full of legends, moral stories and local folk tales all woven into an elaborate narrative educating us the true nature of the Self, Supreme Divine, Humanity, the Code of Civil Conduct, Family Sacrifices, State Governance, Eternity of the Elders, Duty of Citizens, Unity of Command, Ethos of Joint Undivided Family Culture of the ancient India, Clinging to Truth, Friendship, Pure Universal Love, Honesty and Integrity and above all the Law of the Land.

\section{Copyright Disclaimer}

Copyright for this article is retained by the author(s), with first publication rights granted to the journal.

This is an open-access article distributed under the terms and conditions of the Creative Commons Attribution license (http://creativecommons.org/licenses/by/4.0/). 